\title{
PENERAPAN PENDEKATAN CONTEXTUAL TEACHING AND LEARNING PADA MATERI RELASI DAN FUNGSI DI KELAS VIII SMP NEGERI 1 DARUSSALAM ACEH BESAR
}

\author{
Darwani ${ }^{1}$, M.Yacoeb Harun ${ }^{1}$, Suhartati ${ }^{2}$ \\ ${ }^{1}$ Universitas Islam Negeri Ar-Raniry, Jalan Syeikh Abdur Rauf, Banda Aceh 23111, Indonesia \\ ${ }^{2}$ Universitas Syiah Kuala, Jalan T.Chik Pante Kulu, Banda Aceh, 23111, Indonesia \\ Email : darwani_syarifuddin@yahoo.com
}

\begin{abstract}
Abstrak
Konsep relasi dan fungsi merupakan pelajaran yang dianggap sulit diingat oleh siswa. Oleh karena itu, dibutuhkan suatu pembelajaran yang dapat membuat siswa aktif dan kreatif dalam mengkonstruksi ide-idenya melalui pendekatan untuk membentuk suatu pemahaman matematika. Dengan pendekatan Contextual Teaching and Learning (CTL) siswa diharapkan dapat dengan mudah memahami materi pelajaran yang dikaitkan dengan kehidupan sehari-hari siswa. Penelitian ini bertujuan untuk mengetahui keberhasilan belajar siswa menggunakan pendekatan CTL pada materi relasi dan fungsi di kelas VIII SMPN 1 Darussalam Aceh Besar. Rancangan penelitian yang digunakan dalam penelitian ini bersifat eksperimen semu dengan model rancangan one-shot case study dan menggunakan uji statistik, yaitu uji-t. Subjek dalam penelitian ini adalah siswa kelas VIII-1 SMPN 1 Darussalam sebanyak 22 siswa. Berdasarkan hasil analisis data statistik uji-t diperoleh bahwa hasil belajar siswa yang diajarkan melalui pendekatan CTL pada materi relasi dan fungsi mencapai taraf berhasil, kemampuan guru dalam mengelola pembelajaran sudah efektif dengan skor 4,22, aktivitas siswa untuk tiap-tiap kategori pengamatan aktif, serta respon siswa pada setiap komponen pembelajaran positif dengan skor rata-rata keseluruhan 3,25. Jadi, dapat disimpulkan bahwa pendekatan pembelajaran CTL berhasil diterapkan pada materi pembelajaran matematika khususnya pada materi relasi dan fungsi.
\end{abstract}

Kata kunci: Pendekatan CTL, Relasi dan Fungsi, Hasil Belajar

\begin{abstract}
Relation and Fungsion are one of Mathematics concept that hardly retain in students' memory. Therefore, it is important to have a learning activity which can make students become active and creative in constructing their ideas by utilizing an approach that can builds up students' understanding of Mathematics. By using CTL, it is expected that the students can easily understand the learning subject. This is because CTL approach offers a way to relate the subject material to real life situation. The objective of this study is to know how successful students' learning concerning the subjects of Relation and Fungtion through the use of CTL to the second grade students at SMPN 1 Darussalam Aceh Besar. The design of this study is quasi experimantal study in form of one-shot case study and is using statistical test, that is T-Test. The subjects of the study are students class VIII-1 SMPN 1 Darussalam Aceh Besar which consits of 22 students. Students' result on the subject Relation and Fungsion had achieved successful rate due to the use of CTL. Hence, it can be concluded that Contextual Teaching and Learning (CTL) approach is successfully implemented in the subject of Relation and Fungsion.
\end{abstract}

Keywords: Method of Contextual Teaching and Learning, Relation and Function, Learning outcomes 


\section{PENDAHULUAN}

Pendidikan matematika menjadi dasar pemicu bagi mata pelajaran lain untuk dapat mendukung perkembangan ilmu pengetahuan dan teknologi yang lebih modern. Matematika juga termasuk mata pelajaran yang menunjang berbagai perkembangan kehidupan manusia. Eksistensinya cukup brilian dalam memunculkan berbagai situasi dan kondisi. Konsekuensi ini menjadi hebat karena ia termasuk salah satu bidang studi ilmu pengetahuan yang berhubungan dengan angka-angka dan disebut juga dengan ilmu pasti. Dalam hal ini Santoso menambahkan bahwa: "Kemajuan negaranegara maju hingga sekarang lebih dominan mengembangkan matematika hingga mencapai $60 \% \mathrm{~s} / \mathrm{d}$ $80 \%$ dari bidang lainnya". Dari pendapat tersebut dapat dipahami bahwa matematika sangat berperan dalam mengembangkan pemikiran manusia untuk menemukan ide-ide yang dapat berguna bagi perkembangan teknologi di masa akan datang.

Matematika adalah salah satu mata pelajaran yang diterapkan di berbagai tingkat pendidikan, mulai dari SD, SMP, SMA, bahkan sampai perguruan tinggi. Pembelajaran matematika mampu melatih manusia untuk belajar berfikir logis, bersikap kritis dan kreatif serta sistematis dalam setiap tindakannya. Matematika telah menjadi figur sekaligus dasar pengetahuan bagi ilmu-ilmu yang lain. Bahkan kedewasaan suatu ilmu pengetahuan sangat ditentukan oleh adanya peran ilmu matematika. Eksistensi matematika selalu dibutuhkan oleh berbagai pengembang ilmu pengetahuan lainnya. Kehidupannya terus berkembang sejalan dengan tuntutan kebutuhan umat manusia. Karena itu, tidak ada kegiatan manusia yang terlepas dari perannya matematika.

Pembelajaran matematika yang selama ini dilaksanakan di jenjang persekolahan, kebanyakan memaksimalkan orientasinya pada pencapaian keabstrakan objek matematika dan model pembelajaran yang kurang tepat, kondisi ini telah menjadi salah satu faktor sulitnya pemahaman siswa terhadap pembelajaran matematika (Usman, 2006). Konsekuensi ini telah membuat matematika kurang bermanfaat dalam kehidupannya. Problema seperti ini telah merespon siswa merasa dipaksa untuk mempelajari sesuatu yang berada di luar jangkauan daya berfikirnya. Keberhasilan proses belajar tidaklah tergantung pada siswa seluruhnya, melainkan terdapat dua hal yang ikut menentukan keberhasilan dan proses kegiatan belajar mengajar, yakni pengaturan proses belajar mengajar dan pengajaran itu sendiri. Kedua hal tersebut saling mempunyai ketergantungan satu sama lain. "Kemampuan mengatur proses belajar mengajar yang baik akan menciptakan situasi yang memungkinkan anak belajar, sehingga ini menjadi titik awal keberhasilan pengajaran."

Guru dapat menciptakan proses belajar mengajar yang baik dengan menggunakan berbagai pendekatan pembelajaran untuk mengatasi hal tersebut. Pendekatan pembelajaran digunakan untuk menciptakan kelas yang kondusif dan tidak membosankan siswa. Penggunaan pendekatan pembelajaran akan sangat membantu peserta mencapai tujuan pembelajaran. Maka dari itu salah satu pendekatan yang digunakan adalah pendekatan Contextual Teaching Learning (CTL). Pendekatan CTL ini berasal dari kata Contextual yang berarti “ hubungan, konteks, Susana atau keadaan". Sehingga CTL dapat diartikan sebagai suatu pembelajaran yang berhubungan dengan suasana tertentu. Pembelajaran kontekstual didasarkan pada hasil penelitian Jonh Dewey (1916) dalam Johar yang menyimpulkan bahwa "siswa akan belajar dengan baik jika apa yang dipelajari terkait dengan apa yang telah diketahui dan dengan kegiatan atau peristiwa yang terjadi di sekelilingnya".

Hal ini sangat terkait dengan pembelajaran matematika, dalam hal ini materi relasi dan fungsi. Di mana materi tersebut tidak akan berjalan dengan lancar apabila pembelajarannya tidak dikaitkan dengan kehidupan sehari-hari. Adapun kelebihan pembelajaran pendekatan CTL adalah pembelajaran menjadi lebih bermakna dan riil, artinya siswa dituntut untuk dapat menangkap hubungan antara pengalaman belajar di sekolah dengan kehidupan nyata, pembelajaran lebih produktif dan mampu menumbuhkan penguatan konsep kepada siswa karena pendekatan CTL menganut aliran 
konstruksivisme di mana seorang siswa dituntun untuk menemukan pengetahuannya sendiri (Johar, 2006).

Mengatasi kesulitan-kesulitan siswa tersebut guru harus menyadari tentang perlunya penguasaan berbagai jenis metode pembelajaran yang dapat dipergunakan di dalam kelas guna mencapai tujuan pembelajaran. Sehingga perlu dikembangkan metode pembelajaran yang dapat meningkatkan hasil belajar siswa, mengharuskan siswa untuk berpartisipasi aktif, belajar menyelesaikan masalah dan dapat meningkatkan semangat dan motivasi siswa.

Berdasarkan pengamatan peneliti, kenyataan yang terjadi di sekolah-sekolah, saat mengajarkan materi matematika guru jarang sekali menerapkan pendekatan pembelajaran CTL. Pembelajaran matematika yang berlangsung masih berpusat pada guru. Dalam hal ini siswa hanya mendengarkan penjelasan guru, mencatat, mendengarkan saja atau menjawab soal. Problema itu telah menjadikan siswa tidak ikut berperan dalam menemukan konsep dan mengaplikasikannya dalam soal, mereka hanya menunggu jawaban dari guru atau teman-teman yang lebih pandai. Proses pembelajaran yang demikian dapat menyebabkan siswa malas belajar matematika dan selalu menanggap matematika itu pelajaran yang paling menyeramkan. Seperti halnya pada materi relasi dan fungsi yang merupakan salah satu pokok bahasan matematika yang erat sekali kaitannya dengan kehidupan seharihari. Penerapannya dalam kehidupan nyata selalu dibutuhkan, misalnya untuk melihat hubungan ayah dengan anaknya, hubungan siswa dengan kegemarannya . Oleh sebab itu, siswa dituntut untuk dapat menguasai materi yang disampaikan tentang pengertian relasi dan fungsi, perbedaan relasi dengan fungsi, dan cara menyatakan relasi dan fungsi.

Jika menyatakan relasi dan fungsi akan menyulitkan siswa dalam membedakan antara relasi dan fungsi karena bentuk dan cara menyatakannya sama. Banyak sekali pengaruh perbedaan relasi dan fungsi untuk materi fungsi selanjutnya, namun jika siswa tidak aktif dalam belajar dan tidak dikaitkan dengan kehidupan sehari-hari maka materi ini dianggap sangat sulit untuk dipelajari. Selain itu dalam proses pembelajaran, siswa akan malas belajar matematika dikarenakan siswa tidak paham apa makna materi matematika yang sedang dipelajari dalam kehidupan mereka sehari-hari. Siswa juga merasa malas dan enggan untuk mengingat perbedaan relasi dan fungsi dikarenakan pembelajaran yang kurang menyenangkan. Jadi untuk membantu siswa mengatasi kesulitan tersebut adalah dengan menggunakan pendekatan CTL dalam proses pembelajaran.

Adapun tujuan dari penelitian ini adalah sebagai berikut :

- Untuk menegetahui hasil belajar siswa dengan menerapkan pendekatan CTL pada materi relasi dan fungsi di kelas VIII SMP Negeri 1 Darussalam Aceh Besar

- Untuk mengetahui aktivitas siswa dan guru dalam pembelajaran dengan menerapkan pendekatan CTL pada materi relasi dan fungsi di kelas VIII SMP Negeri 1 Darussalam Aceh besar

- Untuk mengetahui kemampuan guru dalam mengelola pembelajaran dengan menerapkan pendekatan CTL pada materi relasi dan fungsi di kelas VIII SMP Negeri 1 Darussalam Aceh besar.

- Untuk mengetahui respon siswa terhadap pelaksanaan pembelajaran matematika pada materi relasi dan fungsi dengan menerapkan pendekatan CTL di kelas VIII SMP Negeri 1 Darussalam Aceh besar.

\section{METODE PENELITIAN}

Pendekatan yang peneliti gunakan dalam penelitian ini adalah pendekatan kuantitatif dan didukung oleh pendekatan kualitatif. Pendekatan yang dimaksud di sini lebih mengacu kepada jenis penelitian yang dilakukan, terletak pada cara peneliti menganalisis data. Metode penelitian yang peneliti gunakan adalah Quasi Experimental Design dengan jenis The One Shot Case Study. Pada penelitian ini hanya melibatkan satu kelas saja yang mendapatkan perlakuan pembelajaran dengan 
menggunakan pendekatan CTL. Populasi dalam penelitian ini adalah siswa kelas VIII SMPN 1 Darussalam Aceh Besar, yang terdiri sebanyak 4 kelas yaitu $\mathrm{VIII}_{1}, \mathrm{VIII}_{2}, \mathrm{VIII}_{3}$, dan $\mathrm{VIII}_{4}$. Sedangkan yang menjadi sampel dalam penelitian ini adalah sebanyak satu kelas yaitu siswa kelas VIII ${ }_{1}$ SMPN 1 Darussalam Aceh Besar dengan jumlah siswa sebanyak 22 orang.

Instrumen yang digunakan dalam penelitian ini adalah lembar tes hasil belajar, lembar observasi dan lembar angket. Adapun pengumpulan data yang dilakukan oleh peneliti dalam penelitian ini adalah: tes, observasi yaitu observasi kemampuan guru dan aktivitas siswa, dan angket. Data yang akan dikumpulkan dalam penelitian ini adalah data hasil belajar siswa dengan menggunakan pendekatan CTL pada materi relasi dan fungsi, data kemampuan guru dalam mengelola pembelajaran, data aktivitas siswa selama pembelajaran berlangsung dan data respon siswa terhadap pembelajaran dengan menggunakan pendekatan CTL. Data yang telah diperoleh selanjutnya diolah menggunakan ketentuan sebagai berikut:

\section{Analisis Data Hasil Belajar Siswa}

Keberhasilan hasil belajar siswa dengan penerapan pendekatan CTL dapat dianalisis dengan menggunakan uji-t dengan terlebih dahulu menguji normalitas data dengan uji chi-kuadrat sebagai berikut:

$$
\begin{aligned}
& x^{2}=\quad \sum_{i=1}^{k} \frac{\left(f_{0}-f_{e}\right)^{2}}{f_{e}} \\
& \text { Dengan: } x^{2}=\text { Statistik chi-kuadrat } \\
& f_{e}=\text { Frekuensi yang diharapkan } \\
& f_{0}=\text { Frekuensi pengamatan }
\end{aligned}
$$

Uji-t yang digunakan adalah sebagai berikut :

$$
\begin{aligned}
& \mathrm{t}=\frac{\bar{x}-\mu_{0}}{s / \sqrt{n}} \\
& \text { Keterangan : } \\
& -x=\text { Nilai rata-rata kelas ekperimen } \\
& \mathrm{n}=\text { Jumlah siswa kelas ekperimen } \\
& \mu_{0}=\text { Standar keberhasilan belajar siswa } \\
& \mathrm{S}=\text { Simpangan baku kelas eksperimen } \\
& \mathrm{t}=\text { Nilai yang dihitung }
\end{aligned}
$$

Selanjutnya menentukan nilai $\mathrm{t}$ dari tabel dengan derajat kebebasan $\mathrm{dk}=\mathrm{n}-1$ dan peluang $(1-\alpha)$ dengan taraf signifikan $\alpha=0,05$. Kriteria pengujian adalah tolak $H_{0}$ jika $t_{\text {hitung }} \geq t_{\text {tabel }}$ dan terima $\mathrm{H}_{0}$ dalam hal lainnya. Nilai KKM yang harus dicapai oleh siswa adalah $\geq 65$.

\section{Analisis Data Aktifitas Siswa}

Data yang diperoleh berdasarkan hasil observasi terhadap aktivitas siswa dengan menerapkan pendekatan CTL dianalisis dengan menggunakan rumus persentase, adapun rumus persentase sebagai berikut:

$$
\frac{\text { rata }- \text { rata frekuensi setiap aspek pengamatan }}{\text { rata }- \text { rata frekuensi }} \times 100 \%
$$




\section{Analisis Data Kemampuan Guru Mengelola Pembelajaran}

Data kemampuan guru dalam mengelola pembelajaran dengan penerapan metode penemuan terbimbing dianalisis dengan menggunakan rumus skor rata-rata. Adapun pendeskripsian skor ratarata tingkat kemampuan guru (TKG) sebagai berikut:

$$
\begin{array}{ll}
1,00 \leq \mathrm{TKG} \leq 1,50 & : \text { Sangat kurang baik } \\
1,50<\mathrm{TKG} \leq 2,50 & : \text { Kurang baik } \\
2,50<\mathrm{TKG} \leq 3,50 & : \text { Cukup } \\
3,50<\mathrm{TKG} \leq 4,50 & : \text { Baik } \\
4,50<\mathrm{TKG} \leq 5,00 & : \text { Sangat baik }
\end{array}
$$

Keterangan: $\mathrm{TKG}=$ Tingkat Kemampuan Guru

Kemampuan guru mengelola pembelajaran dikatakan efektif jika skor dari setiap aspek yang dinilai berada pada kategori baik atau sangat baik.

\section{Data Respon Siswa}

Untuk mengetahui respon siswa maka dianalisis dengan menghitung rata-rata keseluruhan skor yang telah dibuat dengan model skala Likert. Dalam menskor skala kategori Likert, jawaban diberi bobot atau disamakan dengan nilai kuantitatif 4,3,2,1 untuk pernyataan positif dan 1,2,3,4 untuk pernyataan bersifat negatif. Pada penelitian untuk pernyataan positif maka diberi skor 4 untuk sangat setuju, 3 untuk setuju, 2 untuk tidak setuju dan 1 untuk sangat tidak setuju. Sedangkan untuk pernyatan negatif diberi skor sebaliknya yaitu 1 untuk sangat setuju, 2 untuk setuju, 3 untuk tidak setuju, 4 untuk sangat tidak setuju. Skor rata-rata respon siswa dapat dihitung dengan rumus sebagai berikut:

Kriteria skor rata-rata untuk respon siswa adalah sebagai berikut:

$3<$ skor rata-rata $\leq 4=$ sangat positif

$2<$ skor rata-rata $\leq 3=$ positif

$1<$ skor rata-rata $\leq 2=$ negatif

\section{HASIL PENELITIAN DAN PEMBAHASAN}

Tabel 1. Data Nilai Hasil Belajar siswa

\begin{tabular}{|c|c|c|c|}
\hline $\begin{array}{c}\text { No } \\
\text { Urut }\end{array}$ & Subjek & $\begin{array}{c}\text { Jumlah } \\
\text { Skor }\end{array}$ & Keterangan \\
\hline 1. & $\mathbf{0 1}$ & $\mathbf{9 8}$ & Tuntas \\
\hline 2. & 02 & 97 & Tuntas \\
\hline 3. & 03 & 98 & Tuntas \\
\hline 4. & 04 & 100 & Tuntas \\
\hline 5. & 05 & 79 & Tuntas \\
\hline 6. & $\mathbf{0 6}$ & $\mathbf{9 3}$ & Tuntas \\
\hline 7. & 07 & 93 & Tuntas \\
\hline 8. & 08 & 76 & Tuntas \\
\hline 9. & 09 & 81 & Tuntas \\
\hline 10. & 10 & 83 & Tuntas \\
\hline 11. & $\mathbf{1 1}$ & $\mathbf{9 8}$ & Tuntas \\
\hline 12. & 12 & 81 & Tuntas \\
\hline 13. & 13 & 98 & Tuntas \\
\hline 14. & $\mathbf{1 4}$ & $\mathbf{8 7}$ & Tuntas \\
\hline 15. & 15 & 92 & Tuntas \\
\hline
\end{tabular}




\begin{tabular}{|c|c|c|c|}
\hline 16. & $\mathbf{1 6}$ & $\mathbf{5 0}$ & Tidak Tuntas \\
\hline 17. & 17 & 78 & Tuntas \\
\hline 18. & $\mathbf{1 8}$ & $\mathbf{9 0}$ & Tuntas \\
\hline 19. & 19 & 76 & Tuntas \\
\hline 20. & 20 & 89 & Tuntas \\
\hline 21. & 21 & 94 & Tuntas \\
\hline 22. & 22 & 76 & Tuntas \\
\hline
\end{tabular}

Dari tabel.1 di atas terlihat bahwa sebanyak 21 orang siswa tuntas mengikuti pembelajaran dengan menggunakan pendekatan CTL pada materi relasi dan fungsi, selebihnya yaitu sebanyak 1 orang siswa adalah tidak tuntas dengan nilai $\mathrm{KKM} \geq 65$. Dalam persentase jumlah ketuntasan siswa dapat dinyatakan sebanyak $95,5 \%$.

\section{Deskripsi Aktivitas Siswa}

Berdasarkan hasil perhitungan data aktivitas siswa selama pembelajaran menunjukkan presentase yang diperoleh bahwa pembelajaran dengan menerapkan pendekatan CTL pada materi relasi dan fungsi siswa terlibat secara aktif dalam kegiatan pembelajaran. Sehingga dapat disimpulkan bahwa aktivitas siswa untuk masing-masing kategori adalah aktif. Pembelajaran dikatakan efektif apabila siswa terlibat secara aktif dalam proses pembelajaran.

\section{Deskripsi Kemampuan Guru Mengelola Pembelajaran}

Hasil pengamatan kemampuan guru dalam mengelola pembelajaran memperoleh skor rata-rata keseluruhan yaitu 4,22, dapat disimpulkan bahwa guru telah melaksanakan kegiatan pembelajaran dengan baik dan berdasarkan kriteria yang telah ditetapkan, maka kemampuan guru mengelola pembelajaran dengan menerapkan pendekatan CTL dikatakan baik. Sesuai dengan pendapat Slavin bahwa keefektifan belajar lebih menekankan pada kemampuan guru dalam mengelola pembelajaran serta kesesuaian waktu dalam menyelesaikan pelajaran dengan waktu yang direncanakan.

\section{Deskripsi Respon Siswa}

Respon siswa untuk setiap pertanyaan berkisar antara sangat positif dan positif atau dapat dikatakan respon siswa tehadap pembelajaran melalui pendekatan CTL adalah sangat baik dan baik, dan berdasarkan nilai rata-rata keseluruhan diperoleh skor 3,25, maka berdasarkan kriteria yang telah ditetapkan dapat disimpulkan bahwa respon siswa tehadap pembelajaran melalui pendekatan CTL sangat positif.

\section{KESIMPULAN}

Berdasarkan hasil penelitian tentang penerapan pendekatan CTL pada materi relasi dan fungsi di kelas VIII SMPN 1 Darussalam Aceh Besar, maka dapat disimpulkan bahwa:

- Hasil belajar siswa yang diajarkan melalui pendekatan CTL pada materi relasi dan fungsi di kelas VIII SMP Negeri 1 Darussalam Aceh besar mencapai taraf berhasil. Tidak dibandingkan dengan metode lain disebabkan peneliti tidak melakukan perbandingan.

- Siswa aktif selama berlangsungnya pendekatan CTL pada materi relasi dan fungsi untuk setiap kategori pengamatan.

- Kemampuan guru dalam mengelola pembelajaran dalam kategori baik dengan skor rata-rata keseluruhan 4,22.

Respon siswa terhadap pendekatan CTL pada materi relasi dan fungsi termasuk dalam kategori positif dengan skor rata-rata 3,25. 


\section{REFERENCES}

Ahmad Rohani. (2004). Pengelolaan Pengajaran, Jakarta: Rineka Cipta.

Azhar Arsyad. (2007) Media Pembelajaran, Jakarta: Rajagrafindo Persada.

Erman Suherman. (2003) Strategi Pembelajaran Matematika Kontemporer, Jakarta: Universitas Indonesia.

Imam Slamet Santoso. (1997) Perkembangan Kurikulum Matematika dan Pelaksanaan Didepan Kelas, Surabaya: Erlangga.

Moh. User Usman. Menjadi Guru Profesional; Cet. XVII, Bandung: Remaja Rosdakarya, 2005.

Nurhadi. (2003) Pendekatan Kontekstual, Jakarta: Departemen Pendidikan.

Rahmah Johar, dkk.. Strategi Belajar Mengajar, Banda Aceh: Universitas Syiah Kuala, 2006.

Slavin, RE. (1994) Educational Psychology: Theories and Practice. (Fourth Edition), Masschusetss: Allyn and Bacon Publishers.

Syaiful Bahri Djamarah dan Anwar Zain. (1995) Strategi Belajar Mengajar, Jakarta: Rhineka Cipta.

Sudjana.(2005) Metoda Stasistika, Bandung: Tarsito

Suharsimi Arikunto. (2006) Prosedur Penelitian suatu Pendekatan Praktek, Jakarta: Rineka Cipta.

Sukardi. (2004) Metodelogi Penelitian, Jakarta: Bumi Aksara.

Sumadi Suryabrata. (2005) Metodologi Penelitian; Universitas Gadjah Mada, Jakarta: Raja Grafindo Persada.

Wina Sanjaya. (2006) Strategi Pembelajaran Berorientasi Standar Proses Pendidikan, Jakarta: Kencana. 